\title{
Effectiveness of Temephos and Source Reduction Control For Aedes Aegypti Field Population In Makassar City, Indonesia
}

\author{
Hasanuddin Ishak \\ \{hasanuddin.ishak@unhas.ac.id\} \\ Department of Environmental Health, Faculty of Public Health Hasanuddin University, Makassar, \\ Indonesia; Jl. Perintis Kemerdekaan KM.10 Makassar 90245, Sulawesi Selatan, Indonesia
}

\begin{abstract}
Dengue Fever is a disease caused by the dengue virus and is transmitted by the mosquito Aedes aegypti. The study aims to analyze the effectiveness of larvicide temephos $1 \%$ and that the relationship between source reduction $3 \mathrm{M}$ (regular cleaning, covering, burying) with larval density. This study was a quasi-experiment. The research was conducted at Paccerakang and Tamalanrea Villages, Makassar City. Samples were taken by the purposive sampling technique with the primary and secondary data. The study results showed that the Larvicid temephos $1 \%$ had effectivity to decreasing more larvae density at both villages treated (temephos 1\%) areas than those untreated (source reduction) areas. In Pacerakang, the Larva density decrease of House Index $(\mathrm{HI})=25.0 \%$ vs $9.4 \%$, Container Index $(\mathrm{CI})=15,6 \%$ vs $3.5 \%$, Breteau Index $(\mathrm{BI})=$ $31,3 \%$ vs $6.2 \%$. In Tamalanrea, the larva density decrease of $\mathrm{HI}=25.0 \%$ vs $0.0 \%$; $\mathrm{CI}=$ $15.7 \%$ vs $1.5 \%$, and $\mathrm{BI}=25 \%$ vs $3.1 \%$. There was the relationship between the cleaning container $(\mathrm{p}=0.00<0,05)$, and the covering container $(\mathrm{p}=0.00<0,05)$, but that was not the burrying discarded container with Aedes aegypti larval densities $(\mathrm{p}>0,05)$. There was the relationship between the container type $(\mathrm{p}=0.00<0,05)$, the container material $(\mathrm{p}=0.00<0,05)$, the container water conditions with Aedes aegypti larval densities $(\mathrm{p}=0.02<0,05)$.
\end{abstract}

Keywords: Dengue Vector, Temephos, Source Reduction 3M, Larva Density.

\section{Introduction}

Dengue Hemorrhagic Fever (DHF) in Indonesia has become a public health problem in the past 48 years. Since 1968 DHF has spread in 33 provinces and 436 cities out of 497 cities (88\%) [1]. From 2010 to 2014, Incidence Rate and Case Fatality Rate (CFR) of dengue cases in Indonesia tended to fluctuate [1]. DHF cases of Makassar City tend to fluctuate from year to year. DHF cases in Makassar City in the last 10 years starting from 2007-2016 were reported as many as 2,045 cases. In 2007 DHF cases were reported in 457 cases with 10 cases of death; and in 2016, there were 250 cases of DHF found in Makassar City [2].

Eradication of Mosquito Nests (PSN) is one way to control Dengue vector, by doing 3M (regular cleaning, covering, burying) Program, which is cleaning water reservoirs at least once a week, closing water reservoirs tightly and burying/removing used items that can be a breeding place of Aedes aegypti. As well as the use of abate is the provision of abate powder in places that are flooded with water including bathtubs, flower vases and so on with the aim 
of killing the larvae of Aedes aegypti mosquitoes and preventing the occurrence of dengue outbreaks which are the choices in the effort to eradicate vector of Dengue Hemorrhagic Fever.

Research conducted by Azlina et al. (2016) showed that there was a significant relationship between PSN actions and the presence of DHF vector larvae [3]. Another study conducted by Nurjanah (2013) showed that there was a correlation between the dengue incidence and the practice of draining water storage sites and disposing of garbage [4]. While the practice of covering container and access to clean water, that there was no correlation with the dengue incidence. Larvae density data can be used to predict the magnitude of the risk of dengue disease transmission.

Various efforts to control dengue fever have been carried out both physically, biologically, and chemically but still not provide satisfactory results. The study aims to analyze the effectiveness of larvicide temephos $1 \%$ and that the relationship between source reduction 3M (regular cleaning, covering, burying) with larval density.

\section{Methods}

This study was a quasi-experiment. The research was conducted at Paccerakang and Tamalanrea Villages, Makassar City. Sampling in this study was conducted with purposive sampling. Container conditions and 3M Mosquito Nest Eradication (PSN) implementation were observed with a Prospective approach. Larva density (CI, HI, BI) according to Ministry of Health RI (2005) was observed before and after the intervention of Temephos $1 \%$ and $3 \mathrm{M}$ [5]. Data analysis was carried out using SPSS 21 for Window and statistical tests using univariate (frequency), bivariate (Chi-square test) and multivariate (Logistic regression) tests.

\section{Results}

The effectiveness of Abate reducing House Index (HI) Container Index (CI), and Breteau Index (BI).The alteration intervention effectively reduced larval density in the Paccerakang area (case), decreased $\mathrm{HI}=25.0 \%(100 \%), \mathrm{CI}=15.62 \%(100 \%)$ and $\mathrm{BI}=$ $31.25 \%(100 \%)$. Whereas, in the endemic area of Tamalanrea (case) abatezation intervention effectively reduced $\mathrm{HI}$ by $=25(100 \%) \mathrm{CI}=15.68(100 \%)$, and $\mathrm{BI}=25(100 \%)($ Table 1$)$.

Table 1. Distribution of House Index, Breteau Index, and Container Index before and after the

\begin{tabular}{cccc}
\hline Village & $\begin{array}{c}\text { Abate intervention } \\
\text { before Intervention }\end{array}$ & $\begin{array}{c}\text { HI, CI, BI, after } \\
\text { Intervention }\end{array}$ & $\begin{array}{c}\text { Effectiven } \\
\text { ess } \\
\text { Density } \\
\text { reduction }\end{array}$ \\
\hline & $\mathrm{HI}=25.0$ & $\mathrm{HI}=0$ & $\mathrm{HI}=25.0$ \\
Paccerakang & $\mathrm{CI}=15.62$ & $\mathrm{CI}=0$ & $\mathrm{CI}=$ \\
$\begin{array}{c}\text { Endemic area } \\
\text { (intervention) }\end{array}$ & $\mathrm{BI}=31.25$ & $\mathrm{BI}=0$ & 15.62 \\
& & & $\mathrm{BI}=$ \\
& & & 31.25
\end{tabular}




\begin{tabular}{clll}
$\begin{array}{c}\text { Paccerakang Non } \\
\text { Endemic area }\end{array}$ & $\mathrm{HI}=31.25$ & $\mathrm{HI}=21.87$ & $\mathrm{HI}$ \\
$\begin{array}{c}\text { (Control) } \\
\text { CI }=18.6\end{array}$ & $\mathrm{BI}=31.25$ & $\mathrm{CI}=15.1$ & $=$ \\
& & $\mathrm{BI}=25.0$ & 9.38 \\
& & $\mathrm{CI}$ \\
$=$ & $\mathrm{HI}=$ \\
Tamalanrea & $\mathrm{HI}=25.0$ & $\mathrm{HI}=0$ & 25.0 \\
$\begin{array}{c}\text { Endemic area } \\
\text { (intervention) }\end{array}$ & $\mathrm{CI}=15.68$ & $\mathrm{CI}=0$ & $\mathrm{CI}=$ \\
& $\mathrm{BI}=25.0$ & & 15.68 \\
& & $\mathrm{BI}=0$ \\
Tamalanrea & $\mathrm{HI}=9.37$ & $\mathrm{HI}=9.37$ & $\mathrm{HI}=0.0$ \\
Non Endemic & $\mathrm{CI}=5.97$ & $\mathrm{CI}=7.46$ & $\mathrm{CI}=-1.49$ \\
area (Control) & $\mathrm{BI}=12.5$ & $\mathrm{BI}=15.62$ & $\mathrm{BI}=-$ \\
& & & 3.12 \\
\hline
\end{tabular}

\subsection{The Relationship between 3M Implementation (Drain) with Aedes aegypti Larvae Density}

Statistical (Chi-Square) test results showed that there was a significant (p-value 0.00 $<0.05)$ relationship between the habit of draining containers with the presence of Aedes aegypti mosquito larvae in the endemic area of Makassar city. In Table 2, it can be seen that the people who performed drain actions, 74 (57.8\%) more than those who did not drain, 54 $(42.2 \%)$.

Table 2 Distribution of the existence of Aedes aegypti larva and its relationship with the habit of draining

\begin{tabular}{|c|c|c|c|c|c|c|c|}
\hline \multirow{3}{*}{$\begin{array}{l}\text { The existence of } \\
\text { Larvae }\end{array}$} & \multicolumn{4}{|c|}{ Drain the Water reservoirs } & \multirow{2}{*}{\multicolumn{2}{|c|}{ Total }} & \multirow{3}{*}{$\mathrm{p}$} \\
\hline & \multicolumn{2}{|l|}{ Yes } & \multicolumn{2}{|c|}{ No } & & & \\
\hline & $\mathrm{n}$ & $\%$ & $\mathrm{n}$ & $\%$ & $\mathrm{n}$ & $\%$ & \\
\hline Negative & 68 & 68.7 & 31 & 31.3 & 99 & 100 & \\
\hline Positive & 6 & 20.7 & 23 & 79.3 & 29 & 100 & 0,00 \\
\hline Total & 74 & 57.8 & 54 & 42.2 & 128 & 100 & \\
\hline
\end{tabular}

\subsection{Relationship of 3M (Covering Container) with Density of Aedes aegypti Larvae}

Statistical (Chi-Square) test results showed that there was a significant (p-value 0.00 $<0.05$ ) relationship between the habit of covering the container with the presence of Aedes aegypti mosquito larvae in the endemic area of Makassar city. More water storage conditions 
in endemic areas use covers as many as $73(57.0 \%)$ and those that do not use water storage cover as much as $55(43.0 \%)$.

Table 3. Distribution of the existence of Aedes aegypti larvae and its relationship with the habit of covering containers

\begin{tabular}{|c|c|c|c|c|c|c|c|}
\hline \multirow[t]{3}{*}{$\begin{array}{c}\text { The existence of } \\
\text { Larvae }\end{array}$} & \multicolumn{4}{|c|}{ The habit of covering containers } & \multicolumn{2}{|c|}{ Total } & \multirow[t]{3}{*}{$\mathrm{P}$} \\
\hline & \multicolumn{2}{|c|}{ Yes } & \multicolumn{2}{|c|}{ No } & & & \\
\hline & $\mathrm{n}$ & $\%$ & $\mathrm{n}$ & $\%$ & $\mathrm{n}$ & $\%$ & \\
\hline Negative & 66 & 66.7 & 33 & 33.3 & 99 & 100 & 0,00 \\
\hline Positive & 7 & 24.1 & 22 & 75.9 & 29 & 100 & \\
\hline Total & 73 & 57.0 & 55 & 43.0 & 128 & 100 & \\
\hline
\end{tabular}

\subsection{Relationship between 3M (Burying) and Aedes aegypti Larvae Density}

Statistical (Chi-Square) test results showed that there was no significant (p-value $0.114>0.05)$ relationship between burying used goods habits with the presence of Aedes aegypti larvae in endemic areas of Makassar City. In Table 4, it can be seen that more people do not bury used goods $(93.8 \%)$ and $8(6.3 \%)$ buried.

Table 4. Distribution of the existence of Aedes aegypti larvae and its relationship with the habit of buying used goods

\begin{tabular}{|c|c|c|c|c|c|c|c|}
\hline \multirow{3}{*}{$\begin{array}{c}\text { The existence of } \\
\text { Larvae }\end{array}$} & \multicolumn{4}{|c|}{ Habits of burying used goods } & \multicolumn{2}{|c|}{ Total } & \multirow[t]{3}{*}{$\mathrm{P}$} \\
\hline & \multicolumn{2}{|c|}{ Yes } & \multicolumn{2}{|c|}{ No } & \multirow[b]{2}{*}{$\mathrm{n}$} & \multirow[b]{2}{*}{$\%$} & \\
\hline & $\mathrm{n}$ & $\%$ & $\mathrm{n}$ & $\%$ & & & \\
\hline Negative & 8 & 8.1 & 91 & 91.9 & 99 & 100 & 0,114 \\
\hline Positive & 0 & 0.0 & 29 & 100. & 29 & 100 & \\
\hline Total & 8 & 6.3 & 120 & 93.8 & 128 & 100 & \\
\hline
\end{tabular}

\subsection{Relationship between Container Types with Aedes aegypti Larvae Density}

Statistical (Chi-Square) test results showed that there was a significant (p-value 0.00 $<0.05$ ) relationship between the type of containers with the presence of Aedes aegypti larvae in endemic areas of Makassar City. Based on Table 5, it can be seen that in endemic areas, many people use buckets, which are 153 containers $(53.1 \%)$ and bathtubs as many as $29(10.1 \%)$ containers. 


\subsection{Relationship of Container Materials with the Density of Aedes aegypti Larvae}

Statistical (Chi-Square) test results showed that there was a significant (p-value 0.00 $<0.05$ ) relationship between container material and the presence of Aedes aegypti in the endemic area of Makassar city. The results of the questionnaires and observations can be seen that most residents use container materials made of plastic, which are 179 (76.2\%) containers in the Endemic area.

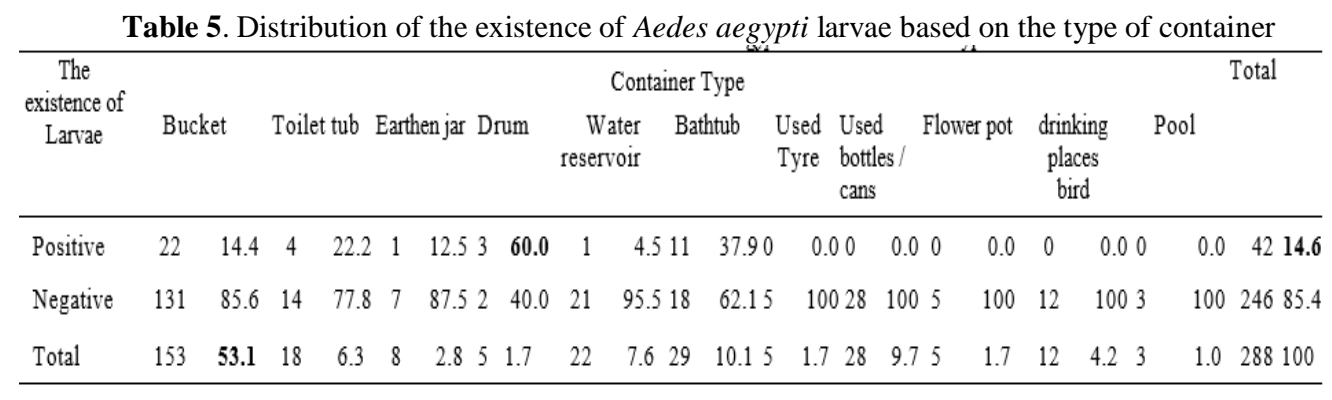

Table 6. Distribution of the existence of Aedes aegypti larvae based on the container material

\begin{tabular}{|c|c|c|c|c|c|c|c|c|c|}
\hline \multirow{2}{*}{$\begin{array}{c}\text { The existence } \\
\text { of Larvae }\end{array}$} & \multicolumn{5}{|c|}{ Container material } & & & \multirow[b]{2}{*}{ Total } & \multirow[b]{2}{*}{$\mathrm{p}$} \\
\hline & Cen & nent & Soil & Ceramics & Plastic & & rubber & & \\
\hline Positive & 7 & 50.0 & 112.5 & $7 \quad 20.6$ & 2511.2 & 266.7 & $\begin{array}{ll}0 & 0.0\end{array}$ & $42 \quad 14.6$ & 0,00 \\
\hline Negative & 7 & 50.0 & 787.527 & 79.4 & 19988.8 & 133.3 & 5100.0 & 24685.4 & \\
\hline Total & 14 & 4.9 & 82.8 & 3411.8 & $224^{77.8}$ & $3 \quad 1.0$ & 1.7 & 288100 & \\
\hline
\end{tabular}

\subsection{Relationship of container water conditions with the density of Aedes aegypti larvae}

Statistical (Chi-Square) test results showed that there was a significant (p-value 0.02 $<0.05)$ relationship between the condition of the water container with the presence of Aedes aegypti mosquito in the endemic area of Makassar City. Based on the results of questionnaires and observations it can be seen that the water conditions of the people in endemic areas are more clear, which are 158 (54.9\%) and turbid water conditions of $130(45.1 \%)$.

Table 8 Distribution of the existence of Aedes aegypti larvae based on Water Conditions of

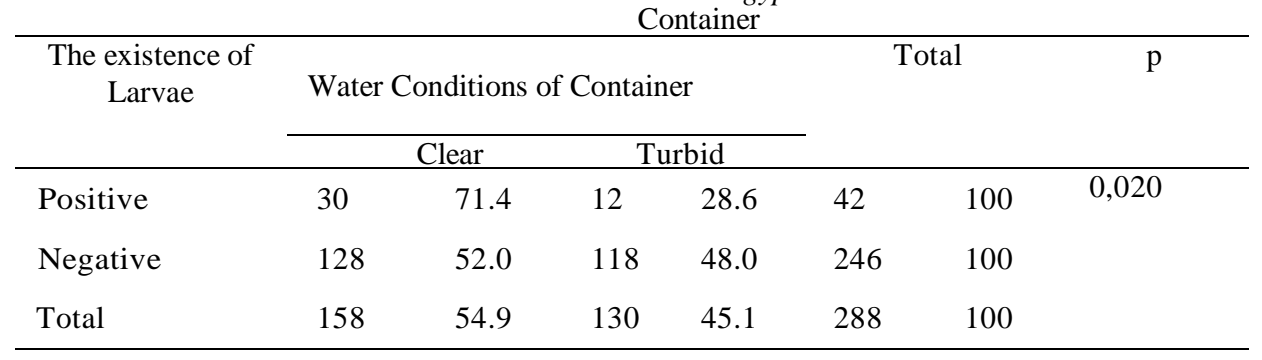




\section{Discussions}

This study shows that the effectiveness of abatezation interventions reducing HI by $15.63 \%$, BI by $21.88 \%$ and CI by $10.94 \%$ in the Paccerakang area (case). Whereas, in the endemic area of Tamalanrea (case), the effectiveness of abatezation intervention reduced $\mathrm{HI}$ by $15.63 \%$, BI by $9.8 \%$ and CI by $15.63 \%$.

This research is similar to Yunita's (2015) study that there was a relationship between abatezation, 3M behavior, and the presence of Aedes aegypti larvae [6]. Some factors that can affect the effectiveness of giving abate powder are the bioecological factors of the larvae, namely how the environmental factors influence the life of the larvae, both physical, chemical, and biological environment.

This study shows that there was a relationship between the habit of draining containers with the presence of Aedes aegypti mosquito larvae in the endemic area of DHF in Makassar city. This research is similar with research conducted by Budiman (2016) which states that there was a relationship between the implementation of draining water reservoirs and the presence of Aedes aegypti mosquito larvae in the village of Kawua, Poso district [7].

Research conducted by Meydel (2013) found that there was a relationship between the larval density of Aedes aegypti with burying in Kalukuang Village, Tallo District, Makassar City [8]. This research is also in line with Riyadi's (2012) study that there was a relationship between the action of eradicating dengue mosquito nests and the density of Aedes aegypti larvae [9]. The results of Setyobudi's research (2011) showed that community participation in PSN activities was very influential in the presence of Aedes aegypti mosquito larvae [10]. Cleaning or draining has not become a continuous habit, improper draining techniques, drainage times that are more than one week. In many endemic areas, there are many who do not carry out the drainage action because many residents in the house use the water reservoir once, so the water used will be used up when used and the potential for mosquito breeding can be reduced. Also, many respondents who did closing actions did not all meet the requirements because at the time of observation, most containers had a lid but were not tightly closed. With the number of respondents who did not close the action that fulfilled the requirements, it would indirectly cause the density of Aedes aegypti larvae even though in this study did not have a relationship but it must always be considered because if there are larvae, it can be a trigger factor for dengue in the region.

There is no correlation between the habit of burying used goods and the presence of Aedes aegypti mosquito larvae in endemic areas of dengue city in Makassar. This research is in line with the research conducted by Dewi (2014), which shows that burying used goods is not related to the presence of Aedes aegypti larvae in DHF endemic areas, Kassi-Kassi village, Makassar city [11]. In addition, based on the results of observations and observations in the field, there were many people who did not take action to bury used goods, due to the limited land used to bury, and the location of the road that was perfect, making cleaning staff difficult to reach in taking out the waste disposed of by the community. To avoid the occurrence of dengue disease, it is expected that the community to take action to bury or get rid of used goods regularly, especially outside the house.

This study shows that there is a relationship between types of containers with the presence of Aedes aegypti larvae in endemic areas of Makassar City. There is a relationship container material with the presence of Aedes aegypti mosquito in the endemic area in Makassar City; there is a relationship between water container conditions and the presence of Aedes aegypti mosquitoes in endemic areas of Makassar City. The results of this study are in line with Meydel's research, (2013), which shows that the most common types of water reservoirs found 
in larvae are bathtubs and bucket (8). Badrah and Hidayah (2011), the type of container base material is at risk for existence Aedes aegypti larvae are cement then metal, soil, ceramics and plastic [12]. The results are in line with research conducted by Gafur and Saleh (2016), that there is a relationship between container material and the presence of Aedes aegypti larvae [13]. This is because the material from cement is easily mossy, the surface is rough and porous on the walls.

Based on the bionomic Aedes aegypti mosquito, this mosquito really likes to lay down the eggs are in clear water and don't like to put their eggs in dirty / murky water in direct contact with the ground. Aedes aegypti mosquito breeding place is very close with humans who use clean water as daily necessities [14]. According to Setyobudi (2011), container conditions are related to the presence of larvae Aedes aegypti where more clear water is found in Aedes aegypti larvae [10], [15], [16]. In clear water conditions, the larvae of Aedes Aegypti mosquitoes prefer and grow well compared to turbid water.

\section{References}

[1] Ministry of Health of Indonesia.: The situation of Dengue hemorrhagic fever in Indonesia (2014)

[2] Health Office of Makassar City.: Profile of Makassar Health Office in 2016. (2017)

[3] Azlina A, Adrial E and Anas.: Relationship between the Action of Eradicating Mosquito Nests and the Presence of DHF Vector Larvae in Lubuk Buaya Village. Andalas Health J.Vol.5.pp.221-222 (2016)

[4] Nurjanah: Relationship between PSN Practices and Access to Clean Water with DHF Events $J$. Pub. Health Unhas. Vol.pp. (2013)

[5] Ministry of Health of Indonesia.: Prevention and eradication of dengue hemorrhagic fever in Indonesia Jakarta: Director General of PP \& PL (2005)

[6] Yunita.:3M Behavior, Abatezation, Aedes aegypti Larva Density and Its Correlation with DHF cases (Surabaya: FPH Airlangga University).pp. (2015)

[7] Budiman.: Relationship between 3M Activity Implementation and Aedes Aegypti larvae density in Kawua Village, Poso Regency. Health J. Tadulako.Vol. 2 pp 71-72 (2016)

[8] Meydel S. A.: Mapping Distribution of Aedes Aegypti Larvae Density and 3M Implementation with DHF Events in Kalukuang Village Tallo District, Makassar City (Makassar: Faculty of Public Health Hasanuddin University) (2013)

[9] Riyadi A and Ibrahim E.: Mapping of Aedes Aegypti Larvae Density Based on the Eradication of Mosquito Nests (PSN) in Ballaparang Sub-District, Rappocini District, Makassar City. J. Pub. Health Unhas Vol.pp. (2013)

[10] Setyobudi A.; Factors Associated with the Existence of Mosquito Larvae in DHF Endemic Areas in Sananwetan Village, Sananwetan District, Blitar City. pp.273-281 (2011)

[11] Dewi M J.: Relationship between DHF eradication (PSN) and the presence of Aedes aegypti larvae in DHF Endemic Areas Kassi-Kassi Village, Makassar City Makassar City: Faculty of Public Health Hasanuddin University.pp (2013)

[12] Badrah S N and Hidayah 2011.: Relationship Between Aedes Aegypti Mosquito Breeding Sites and Dengue Hemorrhagic Fever Cases in Penajam District, Penajam District, North Penajam Paser Regency. J. Trop. Pharm. Chem. Vol.1.pp150-157

[13] Gafur A and Saleh M.: Relationship between Water Shelter and the Presence of Aedes aegypti larvae in Dinas Housing Type E, Motu Village, Baras District, North Mamuju Regency. Hygiene J. Env. Health Vol.1.pp.92-99 (2016)

[14] Ministry of Health of Indonesia.; National Health System:Jakarta (2004) 
[15] Ishak, H., Ponno, S.: Resistance status in Aedes Aegypti strain from north toraja, Indonesia to malathion and temephos insecticides, Indian Journal of Public Health Research and Development Vol. 9.pp.1345 (2018)

[16] Ishak, H., Sartika, J.D., Darmawansyah.: Relationship of rainfall, population density, and human behavior with DHF incidence in makassar city. Indian Journal of Public Health Research and Development (2019) 